\title{
Hepatitis B virus surface antigen seroconversion in HIV-infected individual after pegylated interferon-alpha treatment: a case report
}

\author{
Adriane Maira Delicio ${ }^{1 *}$, Paulo Afonso Martins Abati ${ }^{1}$ and Aline Gonzalez Vigani ${ }^{2}$
}

\begin{abstract}
Hepatitis B virus (HBV) infects from 6 to 14\% of HIV-infected individuals. Concurrent HIV/HBV infection occurs due to the overlapping routes of transmission, particularly sexual and parenteral. HIV-infected patients that have acute hepatitis B have six times greater risk of developing chronic hepatitis B, with higher viral replication, rapid progression to end-stage liver disease and shorter survival. The coinfection is also associated with poor response to hepatitis $B$ treatment with interferon-alpha and increased liver toxicity to the antiretroviral therapy. Herein, we describe the case of a 35-year-old man who engages in sex with men and presented with newly diagnosed HIV-1, serological markers for acute hepatitis B and progression to chronic hepatitis B infection ( $\mathrm{HBsAg}+>6$ months, high alanine aminotransferase levels and moderate hepatitis as indicated by liver biopsy). Lacking indication of antiretroviral treatment (CD4 $\left.768 \mathrm{cell} / \mathrm{s} / \mathrm{mm}^{3}\right)$, he was treated with pegylated-interferon alpha2b $(1.5 \mathrm{mg} / \mathrm{kg} /$ week $)$ by subcutaneous injection for 48 weeks. Twelve weeks after treatment, the patient presented HBeAg seroconversion to anti-HBe. At the end of 48 weeks, he presented HBsAg seroconversion to anti-HBs. One year after treatment, the patient maintained sustained virological response (undetectable HBV-DNA). The initiation of antiretroviral therapy with nucleosides and nucleotides is recommended earlier for coinfected individuals. However, this report emphasizes that pegylated interferon remains an important therapeutic strategy to be considered for selected patients, in whom the initiation of HAART may be delayed.
\end{abstract}

Keywords: HIV, Hepatitis B, HBsAg, Peginterferon

\section{Background}

Worldwide, an estimated two billion people have been infected with the hepatitis B virus (HBV), more than 350 million have chronic liver infection and 34 million live with the human immunodeficiency virus (HIV) infection $[1,2]$. The prevalence of hepatitis B in HIV-infected individuals ranges from 6 to $14 \%$, with higher rates in regions where HBV is endemic, such as Africa and Asia [1,3]. Concurrent infection of HIV with HBV occurs because of the overlapping routes of transmission, particularly sexual and parenteral (injecting drug use and blood transfusion).

In Brazil, the prevalence of coinfection ranges from 5.3 to $24.3 \%$ with significant regional differences [4]. The western Amazon is considered highly endemic for hepatitis B,

\footnotetext{
* Correspondence: adri36_unicamp@hotmail.com

'Campinas Reference Center for Sexually Transmitted Diseases/AIDS,

Campinas, São Paulo State, Brazil

Full list of author information is available at the end of the article
}

in particular because of the coinfection with hepatitis Delta virus (HDV) [1]. In addition, a recent population-based prevalence study in Brazilian state capitals showed that all geographical regions were considered of low endemicity [5]. Acute hepatitis B patients with HIV infection have six times greater risk of developing chronic hepatitis B, with higher viral replication, rapid progression to endstage liver disease and shorter survival [6]. The coinfection is also associated with poor response to hepatitis B treatment with interferon-alpha, lower rates of $\mathrm{HBeAg}$ seroconversion to anti-HBe and HBsAg to anti-HBs, and greater liver toxicity using the antiretroviral therapy [7-10]. Since the introduction of highly active antiretroviral therapy (HAART), liver disease has emerged as an important cause of morbidity and mortality in HIVinfected individuals. Treatment of chronic hepatitis B is based on the use of pegylated interferon or nucleosides and nucleotides polymerase inhibitors. The international 
guidelines recommend the use of pegylated interferon for the treatment of $\mathrm{HBeAg}$ positive coinfected patients that are non-cirrhotic and with no indication for antiretroviral therapy, with limited treatment duration and probably greater chance of viral suppression after discontinuation $[11,12]$.

\section{Case presentation}

We report the case of a 35-year-old male patient who engages in sexual activity with men, followed in the Campinas Reference Center for Sexually Transmitted Diseases/AIDS since January 2009, with newly diagnosed HIV-1 and the following serological markers for hepatitis $\mathrm{B}$ : surface antigen positive ( $\mathrm{HBsAg}+)$, hepatitis $\mathrm{B} e$ antigen positive $(\mathrm{HBeAg}+)$, antibodies to hepatitis $\mathrm{B}$ core antigen positive (anti-HBc IgM+, anti-HBc IgG+), antihepatitis $\mathrm{B} e$ antibody negative (anti-HBe-), and antihepatitis B surface antigen antibody negative (anti-HBs-). $\mathrm{He}$ had a steady partner who presented a diagnosis of hepatitis B with seroconversion to anti-HBs + about four months before the start of the monitoring service and HIV-1 negative at diagnosis of the patient, with seroconversion to HIV-1 positive in 2010.

On physical examination, the patient was in good general condition and his body mass index was $24 \mathrm{~kg} / \mathrm{m}^{2}$. His liver was palpable at $2 \mathrm{~cm}$ from the right costal margin and his spleen was palpable at $2 \mathrm{~cm}$ from the left costal margin. He had no stigmata of chronic liver disease.

In February 2009, CD4+ lymphocyte (CD4) count was 718 cells $/ \mathrm{mm}^{3}$, HIV-1 viral load (VL) was 9399 copies $/ \mathrm{mL}$, aspartate aminotransferase (AST) was $347 \mathrm{IU} / \mathrm{mL}$, alanine aminotransferase (ALT) 604 IU/mL, HBsAg+, HBeAg+, anti-HBc IgG+, anti-HBc IgM+, anti-HBe-, anti-HBs-, antibody for hepatitis $\mathrm{C}$ virus (HCV) negative, and antibody for hepatitis A (HAV) IgG+, IgM- (Table 1).
The biochemical liver function test values were normal. Upper endoscopy showed gastroduodenitis with $H$. pylori positive and total abdominal ultrasound showed no abnormality.

The patient was classified into the first stage of HIV infection (A1), according to the Centers for Disease Control and Prevention (CDC) criteria and acute HBV infection. Then, it was decided to monitor the hepatitis B progress and not initiate antiretroviral therapy.

After eight months of follow-up, the patient had the following laboratory tests results: CD4 768 cells $/ \mathrm{mm}^{3}$, VL 3746 copies $/ \mathrm{mL}$, AST $101 \mathrm{IU} / \mathrm{mL}$, ALT $136 \mathrm{IU} / \mathrm{mL}$, HBsAg+, HBeAg+, anti-HBc IgG+, anti-HBc IgM-, antiHBe-, and anti-HBs- (Table 1).

When chronic hepatitis B (HBsAg+ > 6 months) was confirmed, a liver biopsy was performed resulting in METAVIR score F2A2. Because of the persistence of HBsAg, increased ALT levels and no indication of antiretroviral therapy, treatment was initiated for hepatitis $B$ with pegylated-interferon alpha2b $(80 \mathrm{mcg}), 1.5 \mathrm{mg} / \mathrm{kg}$ once a week, by subcutaneous injection for 48 weeks.

During treatment, the patient developed moderate neutropenia (minimum of 714 neutrophils $/ \mathrm{mL}$ ) controlled by use of filgastrima, thrombocytopenia (minimum of 124,000 platelets $/ \mathrm{mL}$ ), nadir CD4 520 cells $/ \mathrm{mm}^{3}$ and bipolar affective disorder, stabilized on lithium carbonate (Table 1). At 12 weeks of treatment, the patient presented HBeAg seroconversion to antiHBe and normalization of liver enzymes. At the end of 48 weeks of treatment, he presented HBsAg-, anti-HBc IgG+, antiHBs $>1000 \mathrm{mIU} / \mathrm{mL}$ (Figure 1). In May 2012, a year after the end of treatment, the patient showed AST $26 \mathrm{IU} / \mathrm{mL}$, ALT $14 \mathrm{IU} / \mathrm{mL}$, anti-HBc IgG+, anti-HBs 148, CD4 466 cells $/ \mathrm{mm}^{3}$ and HBV-DNA level $<15 \mathrm{IU} / \mathrm{mL}$ (reference values $15-500.000 .000 \mathrm{IU} / \mathrm{mL}$ by real time PCR).

Table 1 Laboratory tests performed during follow-up

\begin{tabular}{|c|c|c|c|c|c|c|c|}
\hline \multirow[t]{2}{*}{ Laboratory tests } & \multicolumn{7}{|c|}{ Date } \\
\hline & Feb. 16, 2009 & Oct. 13, 2009 & May 13, 2010 & Jul. 22, 2010 & Feb. 21, 2011 & Jun. 9, 2011 & May 5, 2012 \\
\hline CD4 (cells/mm³) & 718 & 768 & 678 & 520 & 635 & 597 & 466 \\
\hline HIV viral load (copies/mL) & 9399 & 3746 & 2553 & 79 & 448 & 2536 & - \\
\hline Hemoglobin (g/dL) & 16.7 & 15.2 & 15.4 & 14.6 & 14.0 & 15.5 & - \\
\hline Neutrophils/mL & 2236 & 1867 & 714 & 2436 & 3129 & 2217 & - \\
\hline Platelets $10^{3} / \mathrm{mL}$ & 192 & 187 & 124 & 146 & 173 & 186 & - \\
\hline AST/ALT (IU/mL) & $347 / 604$ & $101 / 136$ & $217 / 223$ & $31 / 31$ & $24 / 14$ & $26 / 16$ & $26 / 14$ \\
\hline $\mathrm{HBsAg}$ & Positive & Positive & - & Positive & Negative & Negative & Negative \\
\hline $\mathrm{HBeAg}$ & Positive & Positive & - & Negative & - & - & - \\
\hline Anti-HBC lgG & Positive & Positive & - & Positive & Positive & Positive & Positive \\
\hline Anti-HBC IgM & Positive & Negative & - & Negative & - & - & - \\
\hline Anti-HBe & Negative & Negative & - & Positive & - & - & - \\
\hline Anti-HBs & Negative & Negative & - & Negative & $>1000$ & 716 & 148 \\
\hline
\end{tabular}




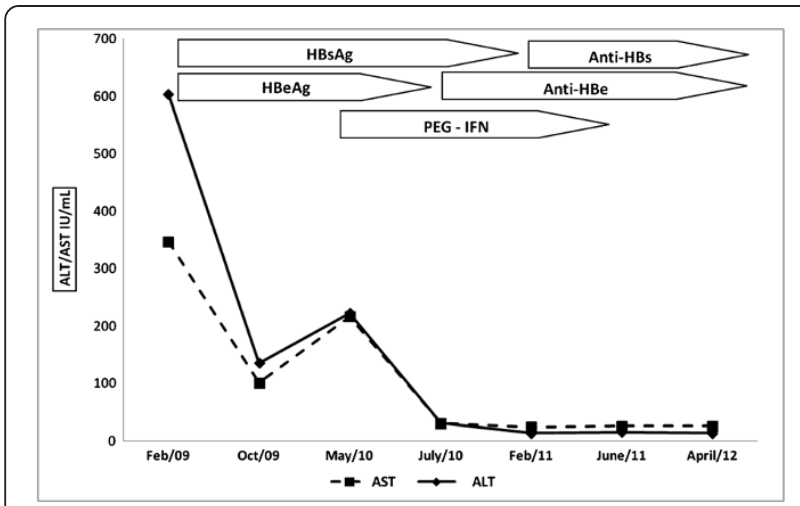

Figure 1 Evolution of biochemical and serological tests before and after treatment.

\section{Discussion}

This report describes the case of a HIV/HBV-coinfected patient, without indication of antiretroviral therapy, who had optimal response to treatment of chronic hepatitis B with pegylated interferon. The patient presented rapid $\mathrm{HBeAg}$ seroconversion to anti-HBe and HBsAg to anti$\mathrm{HBs}$ and sustained virological response one year after the end of therapy.

According to the literature, $\mathrm{HBeAg}$ seroconversion to anti-HBe occurs in up to $30 \%$ of monoinfected individuals in use of pegylated interferon and in up to $28 \%$ of coinfected individuals in use of conventional interferonalpha $[8,11,13,14]$. Furthermore, HBsAg seroconversion to anti-HBs occurs in less than $10 \%$ of the monoinfected and probably in a much smaller proportion of coinfected individuals [15]. However, there are no published studies that evaluate the therapeutic response to pegylated interferon in a representative group of coinfected individuals.

There are few studies showing HBeAg and/or HBsAg seroconversion in coinfected individuals, whether on HAART (nucleoside and nucleotide polymerase inhibitors) or with use of interferon-alpha [16]. In the early 1990s, the first case reporting HBsAg seroconversion in HIV/HBV-coinfected patients treated with conventional interferon-alpha was published [17]. Later, it was reported a case of $\mathrm{HBsAg}$ seroconversion in a $\mathrm{HIV} / \mathrm{HBV} / \mathrm{HCV} / \mathrm{HDV}$-coinfected patient after treatment with pegylated interferon and ribavirin [18]. The most recent report of hepatitis B surface antigen seroconversion in a HIV/HBV-coinfected patient treated with pegylated interferon was described by Rossetti et al. [19] in 2012, with some similarities to our patient.

The lower probability of spontaneous loss of $\mathrm{HBeAg}$ and HBsAg in HIV/HVB-coinfected individuals, as well as lower seroconversion after treatment, may be explained by the impairment of innate and adaptive immunity, with a weak cellular immune response to HBV, typical of HIVinfected patients $[20,21]$. As a cytokine, interferon-alpha acts inhibiting HBV replication through interaction with viral proteins and stimulation of host cellular immunity. Moreover, it is supposed that the best therapeutic response in HIV/HBV-coinfected patients - avoiding antiretroviral therapy and in non-cirrhotic individuals - may be obtained in cases of $\mathrm{HBeAg}$ positive, with higher CD4 counts, lower HBV-DNA levels, higher ALT levels, early stages of liver fibrosis and genotype A [20-24]. Although some authors suggest the importance of quantitative measurement of HBsAg as predictor of virological response and HBsAg seroconversion in monoinfected individuals, it has not been proven yet in HIV/HBV-coinfected individuals $[25,26]$. It is known that HIV infects hepatocytes already infected with HBV and leads to increased intracellular levels of HBsAg, which could contribute to accelerated liver disease in these individuals. HBsAg levels could not be quantified in this study [27].

\section{Conclusion}

Currently, the initiation of antiretroviral therapy with nucleosides and nucleotides is recommended earlier for coinfected individuals, even in patients with higher CD4 counts compared to HIV-monoinfected patients [11,12,28,29]. However, the pegylated interferon remains an important therapeutic strategy to be considered for selected patients, in whom the initiation of HAART may be delayed, aiming at a more effective and lasting response to treatment, with lower risk of progression to cirrhosis and hepatocellular carcinoma, as the example of the patient described in the present study [30].

\section{Consent}

Written informed consent was obtained from the patient for publication of this case report.

\section{Abbreviations \\ ALT: Alanine aminotransferase; Anti-HBc: Antibodies to hepatitis B core antigen; Anti-HBe: Anti-hepatitis B e antibody; Anti-HBs: Anti-hepatitis B surface antigen antibody; AST: Aspartate aminotransferase; CDC: Centers for disease control and prevention; CD4: CD4+ lymphocyte; DNA: Deoxy ribonucleic acid; HAART: Highly active antiretroviral therapy; HAV: Hepatitis A virus; HBV: Hepatitis B virus; HbsAg: Hepatitis B surface antigen; \\ HBeAg: Hepatitis B e antigen; HCV: Hepatitis C virus; HDV: Hepatitis Delta virus; HIV: Human immunodeficiency virus; VL: Viral load; PCR: Polymerase chain reaction.}

\section{Competing interests}

The authors declare that they have no competing interests.

\section{Authors' contributions}

AMD was the responsible doctor for the patient's treatment and conceived the study. AMD and PAMA wrote the literature review and organized the manuscript. AGV reviewed the article. All authors read and approved the final text.

\section{Acknowledgments}

The authors would like to thank Solange Polisel, Lora Ventura, and Felipe Fernandes for their help with language editing. 


\section{Author details}

${ }^{1}$ Campinas Reference Center for Sexually Transmitted Diseases/AIDS, Campinas, São Paulo State, Brazil. ${ }^{2}$ Hepatitis Virus Study Group, University of Campinas (UNICAMP), Campinas, São Paulo State, Brazil.

Received: 22 August 2013 Accepted: 14 November 2013 Published: 10 December 2013

\section{References}

1. World Health Organization: Global Hepatitis Programme. Geneva: WHO; 2012.

2. Health W: Organization: Progress Report, Global HIV/AIDS Response, Epidemic Update and Health Sector Progress towards Universal Access. Geneva: WHO; 2011:2011.

3. Alter MJ: Epidemiology of viral hepatitis and HIV co-infection. $J$ Hepatol 2006, 44(1 Suppl):S6-S9.

4. Brasil. Ministério da Saúde: Coordenação Nacional de DST/AIDS. Brasília: Recomendações para Terapia anti-retroviral em adultos infectados pelo HIV - 2007/2008; 2008.

5. Brasil. Ministério da Saúde: Secretaria de Vigilância em Saúde. Ano II no 01. Brasília: Departamento de DST, Aids e Hepatites Virais: Boletim epidemiológico hepatites virais; 2011.

6. Nikolopoulos GK, Paraskevis D, Hatzitheodorou E, Moschidis Z, Sypsa V Zavitsanos X, Kalapothaki V, Hatzakis A: Impact of hepatitis B virus infection on the progression of AIDS and mortality in HIV-infected individuals: a cohort study and meta-analysis. Clin Infect Dis 2009, 48(12):1763-1771.

7. Bottecchia M, Garcia-Samaniego J, Soriano V: The implications of antiviral drugs with activity against hepatitis B virus and HIV. Curr Opin Infect Dis 2007, 20(6):621-628.

8. Gaglio PJ, Sterling R, Daniels E, Tedaldi E, Terry Beirn community programs for clinical research on AIDS hepatitis working group: Hepatitis B virus and HIV coinfection: results of a survey on treatment practices and recommendations for therapy. Clin Infect Dis 2007, 45(5):618-623.

9. Sulkowski MS, Thomas DL, Chaisson RE, Moore RD: Hepatotoxicity associated with antiretroviral therapy in adults infected with human immunodeficiency virus and the role of hepatitis C or B virus infection. J Am Med Assoc 2000, 283(1):74-80.

10. Law WP, Dore GJ, Duncombe CJ, Mahanontharit A, Boyd MA, Ruxrungtham K Lange JM, Phanuphak P, Cooper DA: Risk of severe hepatotoxicity associated with antiretroviral therapy in the HIV-NAT Cohort, Thailand, 1996-2001. AIDS 2003, 17(15):2191-2199.

11. European association for the study of the liver: EASL clinical practice guidelines: management of chronic hepatitis B virus infection. $J$ Hepatol 2012, 57(1):167-185.

12. Lok ASF, McMahon BJ: American association for the study of liver diseases: AASLD Practice Guidelines. Chronic Hepatitis B: update 2009. Hepatology 2009, 50(3):1-36.

13. Lau GK, Piratvisuth T, Luo KX, Marcellin P, Thongsawat S, Cooksley G, Gane E, Friend MW, Chow WC, Paik SX, Chang WY, Berg T, Flisiak R, McCloud P, Pluck N, Peginterferon Alfa-2a HBeAq-positive chronic hepatitis B study group: Peginterferon Alfa-2a, lamivudine, and the combination for HBeAg-positive chronic hepatitis B. N Engl J Med 2005, 352(26):2682-2695.

14. Janssen $\mathrm{HL}$, van Zonneveld M, Senturk H, Zeuzem S, Akarca US, Cakaloglu Y, Simon C, So TM, Gerken G, de Man RA, Niesters HG, Zondervan P, Hansen B, Schalm SW, HBV 99-01 study group: Pegylated interferon alfa-2b alone or in combination with lamivudine for HBeAg-positive chronic hepatitis B: a randomised trial. Lancet 2005, 365(9454):123-129.

15. Li WC, Wang MR, Kong LB, Ren WG, Zhang YG, Nan YM: Peginterferon alpha-based therapy for chronic hepatitis B focusing on HBsAg clearance or seroconversion: a meta-analysis of controlled clinical trials. BMC Infect Dis 2011, 11:165

16. Martín-Carbonero L, Teixeira T, Poveda E, Plaza Z, Vispo E, Gonzalez-Lahoz J, Soriano $\mathrm{V}$ : Clinical and virological outcomes in HIV-infected patients with chronic hepatitis B on long-term nucleos(t)ide analogues. AIDS 2011, 25(1):73-79

17. Marcellin P, Boyer N, Colin JF, Martinot-Peignoux M, Lefort V, Matheron S, Erlinger $S$, Benhamou JP: Recombinant alpha interferon for chronic hepatitis B in anti-HIV positive patients receiving zidovudine. Gut 1993, 34(2):S106.

18. Gozlan J, Lacombe K, Gault E, Raquin G, Girard PM: Complete cure of HBV/HDV co-infection after 24 weeks of combination therapy with pegylated interferon and ribavirin in a patient co-infected with HBV/ HCV/ HDV/ HIV. J Hepatol 2009, 50(2):432-434.

19. Rossetti B, Bianco C, De Luca A: Hepatitis B virus surface antigen seroconversion after pegylated interferon-alpha treatment in an HIV-infected individual with chronic hepatitis B. Infection 2012, 40(3):347-349.

20. Chang JJ, Sirivichayakul S, Avihingsanon A, Thompson AJV, Revill P, Iser D, Slavin J, Buranapraditkun S, Marks P, Matthews G, Cooper DA, Kent SJ, Cameron PU, Sasadeusz J, Desmond P, Locarnini S, Dore GJ, Ruxrungtham K, Lewin SR: Impaired quality of the hepatitis B virus (HBV)-specific T-cell response in human immunodeficiency virus type 1-HBV coinfection. J Virol 2009, 83(15):7649-7658.

21. Crane M, Sirivichayakul S, Chang JJ, Avihingsanon A, Ubolyam S, Buranapraditkun S, Thantiworasit P, Wightman F, Locarnini S, Matthews G, Dore GJ, Ruxrungtham K, Lewin SR: No Increase in hepatitis B virus (HBV)-specific CD8 ${ }^{+} \mathrm{T}$ cells in patients with HIV-1-HBV coinfections following HBV-Active highly active antiretroviral therapy. J Viro/ 2010, 84(6):2657-2665.

22. Buster EH, Hansen BE, Lau GK, Piratvisuth T, Zeuzem S, Steyerberg EW, Janssen $\mathrm{HJ}$ : Factors that predict response of patients with hepatitis $\mathrm{B}$ e antigen-positive chronic hepatitis B to peginterferon-alfa. Gastroenterology 2009, 137(6):2002-2009.

23. Flink HJ, van Zonneveld M, Hansen BE, de Man RA, Schalm SW, Janssen HL, HBV 99-01 study group: Treatment with Peg-interferon alpha-2b for $\mathrm{HBeAg}$-positive chronic hepatitis B: HBsAg loss is associated with HBV genotype. Am J Gastroenterol 2006, 101(2):297-303.

24. Soriano V, Tuma P, Vispo E, Labarga P, Fernández JV, Medrano J, Barreiro P. Hepatitis B in HIV patients: what is the current treatment and what are the challenges? J HIV Ther 2009, 14(1):13-18.

25. Moucari R, Marcellin P: Quantification of hepatitis B surface antigen: a new concept for the management of chronic hepatitis B. Liver Int 2011, 31(Suppl 1):122-128.

26. Chan $\mathrm{HL}$, Thompson A, Martinot-Peignoux M, Piratvisuth T, Cornberg M, Brunetto MR, Tillmann HL, Kao JH, Jia JD, Wedemeyer H, Locarnini S, Janssen $\mathrm{HL}$, Marcellin P: Hepatitis B surface antigen quantification: why and how to use it in 2011 - a core group report. J Hepatol 2011, 55(5):1121-1131.

27. Iser DM, Warner N, Revill PA, Solomon A, Wightman F, Saleh S, Crane M, Cameron PU, Bowden S, Nguyen T, Pereira CF, Desmond PV, Locarnini SA, Lewin SR: Coinfection of hepatic cell lines with human immunodeficiency virus and hepatitis $B$ virus leads to an increase in intracellular hepatitis $B$ surface antigen. J Virol 2010, 84(12):5860-5867.

28. Zoulim F, Mason WS: Reasons to consider earlier treatment of chronic HBV infections. Gut 2012, 61(3):333-336.

29. Soriano V, Vispo E, Bottecchia M, Sheldon J, Tuma P, Garcia-Samaniego J, Barreiro P: Management of hepatitis $B$ virus co-infection on and off antiretroviral therapy. Curr HIV/AIDS Rep 2008, 5(2):86-93.

30. Buster EH, Schalm SW, Janssen HL: Peginterferon for the treatment of chronic hepatitis B in the era of nucleos(t)ide analogues. Best Pract Res Clin Gastroenterol 2008, 22(6):1093-1108.

doi:10.1186/1678-9199-19-3

Cite this article as: Delicio et al: Hepatitis B virus surface antigen seroconversion in HIV-infected individual after pegylated interferonalpha treatment: a case report. Journal of Venomous Animals and Toxins including Tropical Diseases 2013 19:31.

\section{Submit your next manuscript to BioMed Central and take full advantage of:}

- Convenient online submission

- Thorough peer review

- No space constraints or color figure charges

- Immediate publication on acceptance

- Inclusion in PubMed, CAS, Scopus and Google Scholar

- Research which is freely available for redistribution 